\title{
THE POSSIBILITIES OF APPLYING HEDGING STRATEGIES ON INTERNATIONAL COMMODITY EXCHANGES
}

\author{
Irena Jankovic ${ }^{*}$ \\ Faculty of Economics, University of Belgrade, Belgrade, Republic of Serbia \\ Vlado Kovačević \\ Institute of Agricultural Economics, Belgrade, Republic of Serbia \\ Vladimir Zakić \\ Faculty of Agriculture, University of Belgrade, Belgrade, Republic of Serbia
}

\begin{abstract}
The aim of the paper is to determine the possibilities of implementing hedging strategies of Serbian agricultural producers on foreign commodity exchanges. Considerable fluctuations in prices of agricultural products in Serbia create the need for the use of futures in commodity exchanges in order to protect against unfavourable change in prices of agricultural products in the future period. Due to the fact that Serbia has not established the trading in commodity derivatives, Serbian producers are having to use developed commodity exchanges abroad. The paper analyses the possibilities of using the Chicago Mercantile Exchange in the USA and the MATIF commodity exchange in Paris, looking at two aspects of the activities. First, the correlation of corn prices on domestic and foreign commodity exchanges was investigated, given that it is the basic prerequisite for the application of successful hedging strategies and, secondly, legal requirements, primarily tax policies related to trade of futures contracts. This paper has found that there is a high correlation between the crops price in the foreign commodity markets and spot market in Serbia, which provides a solid basis for the implementation of hedging strategies for underlying assets in foreign commodity markets. However, it has been found that inadequate taxation policy is an aggravating factor for the implementation of hedging strategies.
\end{abstract}

Key words: hedging strategies, commodity exchanges, futures, options, margin accounts.

JEL classification: $Q 02, Q 14, G 15$, F65

*irenajankovicmail@yahoo.com 
46 | THE POSSIBILITIES OF APPLYING HEDGING STRATEGIES ON INTERNATIONAL COMMODITY EXCHANGES

\section{MOGUĆNOSTI PRIMENE HEDŽING STRATEGIJA NA INOSTRANIM ROBNIM BERZAMA}

Sažetak: Cilj rada je utvrđivanje mogućnosti za primenu hedžing strategija srpskih poljoprivrednih proizvođača na inostranim robnim berzama. Visoka fluktacija cena poljoprivrednih proizvoda u Srbiji uslovljava potrebu za korišćenjem terminskih robnih berzi, u cilju zaštite od nepovoljnog kretanja cena poljoprivrednih proizvoda u budućem periodu. S obzirom na to da u Srbiji nije uspostavljeno terminsko trgovanje robnim derivatima, srpski proizvođači su upućeni na korišćenje razvijenih robnih berzi u inostranstvu. U radu su analizirane mogućnosti korišćenja Čikaške robne berze u SAD $i$ MATIF robne berze u Parizu. Izvršena je analiza sa dva aspekta: prvi, korelisanost cena kukuruza sa domaće berze i inostranih berzi, s obzirom na to da je ona osnovni preduslov za primenu uspešnih hedžing strategija i drugi, zakonski uslovi, prevashodno poreske politike $u$ vezi sa trgovinom terminskim ugovorima. U radu je utvrđen visok stepen povezanosti cena žitarica na inostranim robnim berzama i spot tržištu u Srbiji, što daje dobru osnovu za primenu hedžing strategija na ovu baznu aktivu na inostranim robnim berzama. Ipak, neadekvatni poreski propisi otežavaju primenu ovih strategija.

Ključne reči: hedžing strategije, robne berze, fjučersi, opcije, marginski računi.

\section{INTRODUCTION}

The agricultural sector is one of the economy sectors with the highest business risk. There is almost no other sector like agricultural sector with such a change in prices from year to year as well as during the season (Assefa, Meuwissen and Lansink, 2017). Therefore, for successful business operations, it is necessary to efficiently manage the price risk of agricultural products (Zakić and Vasiljević, 2013). Not all instruments for managing the price risk are available to Serbian agricultural producers due to the underdeveloped commodity exchanges in Serbia. The price volatility of agricultural products in the last decade has caused a high business risk in the agricultural sector of Serbia. The main hypothesis in this paper is that is possible for Serbian farmers to apply hedging strategies on foreign commodity exchanges. The possibility of applying hedging strategies would improve the risk management segment in Serbian agricultural sector.

In order to successfully apply hedging strategies on foreign commodity exchanges, high correlation of prices on the commodity exchange and spot prices at which the farmers actually sell agricultural products is required (Gaudenzia, Zsidinsinb, Hartleyc and Kaufmannd, 2018). Expectations regarding the results of the paper are that the correlation of prices in world commodity exchanges and in the spot market in Serbia is significant for corn and wheat. 


\section{HEDGING STRATEGIES}

Irena Janković, Vlado Kovačević, Vladimir Zakić | 47

Agricultural producers in developed market economies have at their disposal numerous instruments for managing the market risk. One of the most commonly used risk management instruments is the hedging strategy in commodity exchanges (Conlon, Cotter and Gençay, 2016).

The mechanism of hedging strategies is based on the sale of agricultural products for delivery/financial settlement in the future period. In practice, farmers use two types of derivative contracts: a futures contract and an options contract (Kovačević, 2014).

A futures contract is a highly standardized forward contract in terms of delivery time $^{\dagger}$, quantity of goods (on the CME, this is an amount of 5,000 bushels of wheat per contract), quality, place of delivery, etc. Buyers can only decide on the number and maturity date of a futures contract, while all the other conditions are standardized (Kolb and Overdahl, 2007).

High standardization leads to possible trading of futures in secondary markets, i.e. farmers can sell their positions and exit the derivative market. All commodity exchange futures contracts involve activities of a clearing house which acts as an intermediary. It is a seller towards a buyer of the futures, and vice versa, it acts as a buyer towards a seller. Both the buyer and the seller of the futures are obliged to pay deposits (margin) to the clearing house's account that are adjusted on a daily basis in such a manner that the funds from the margin account of the party that experiences loss due to daily movement of price are transferred to the margin account of the counterparty. If the amount on the margin account drops below the defined minimum amount, the trader receives a call to increase the account balance (margin call). A margin and a clearing house system guarantees that none of the parties involved in the trading will cease to execute contractual obligations (Arezki, Loungani, Ploeg and Venables, 2014).

Options contracts provide farmers with an opportunity to sell/buy agricultural products/inputs in a future period at a predetermined price. Like the futures contract, they are highly standardized regarding the maturity, quantity, quality and place of delivery of the agricultural products. The difference between a futures and an options contract is that the option buyer decides whether to execute the contract or not. As a cost for an option, the buyer pays the option

\footnotetext{
${ }^{\dagger}$ There are several due dates in a year on which futures mature, typically there are four maturity dates.
} 
48 | THE POSSIBILITIES OF APPLYING HEDGING STRATEGIES ON INTERNATIONAL COMMODITY EXCHANGES

price (premium) ${ }^{\ddagger}$ in exchange for the right granted by the option, so the option is made more secure, but it also has higher costs than the futures contract (Brun, 2018). The option involves activities of clearing house as an intermediary, however, in this case only the seller of the option makes deposits in the margin account.

An example of a hedging strategy on a foreign commodity exchange: In May, a Serbian farmer wants to secure the corn price for November when corn is harvested. The corn future price for November at the Chicago Mercantile Exchange (CME) is $\$ 225$ per ton, which is suitable for a Serbian farmer who decides to sell corn on the CME Stock Exchange at a stated price of $\$ 225$ per ton. In November, the closing price of the futures contract is $\$ 215$ per ton. At the same time (in November), the farmer sells corn on the local market in Serbia at a price of $\$ 215$ per ton.

Table 1

Example of the hedge strategy of a Serbian farmer on the CME Stock Exchange (without the change of the basis)

\begin{tabular}{|c|c|c|c|}
\hline Spot price & Future price & Basis & \\
\hline $\begin{array}{l}\text { Planned price of } \\
225 \$ / \text { ton }\end{array}$ & $\begin{array}{l}\text { Opens a short } \\
\text { position for } \\
\text { November (sells) at } \\
225 \$ / \text { ton }\end{array}$ & / & \\
\hline $\begin{array}{l}\text { November, corn is } \\
\text { sold in Serbia at } \\
215 \text { \$/ton }\end{array}$ & $\begin{array}{l}\text { Corn futures price } \\
\text { in November is } 215 \\
\$ / \text { ton }\end{array}$ & l & \\
\hline \multirow[t]{2}{*}{$\begin{array}{l}\text { Result on the spot } \\
\text { market: } 225-215 \\
\$ / \text { ton }=10 \$ / \text { ton } \\
\text { lower than the } \\
\text { planned price }\end{array}$} & $\begin{array}{l}\text { Gain on the futures } \\
225-215=10 \$ / \text { ton } \\
\text { profit }\end{array}$ & l & $\begin{array}{l}\text { End result } \\
\text { - desired price } 225 \$ / \text { ton } \\
\text { - corn is sold in Serbia at } 215 \\
\$ / \text { ton } \\
\text { - gain on the forward market } 10 \\
\$ / \text { ton }\end{array}$ \\
\hline & & & Total realized price $\mathbf{2 2 5}$ \$/ton \\
\hline
\end{tabular}

Note. Calculated by authors.

The essence of hedging is in the fact that despite the decrease in the price in Serbian market, where the farmer sells the product in relation to the futures price at which the futures are settled, as in the above example, the planned price is protected by a gain on a futures contract. To put it simply, no matter how

\footnotetext{
$\$$ The option seller assumes that the price on the market will not change significantly and deviate from the strike price, and therefore the option will not be activated and he will retain the amount received for the sale of the option.
} 
Irena Janković, Vlado Kovačević, Vladimir Zakić | 49 much the producer loses due to a drop in prices from April to November on the spot market, the producer will gain that much on the other hand due to drop in prices in the forward market, and vice versa, the loss caused by the price increase in the forward market will be annulled by the price increase on the spot market. Therefore, gains and losses on the forward and spot market are completely offset in the case of a perfect hedge (Taušer and Čajka, 2014).

The situation, as in the example above, when the basis does not change, is called the perfect hedge. In practice, the price of an agricultural product on the spot market in Serbia is expected to be different from the price in the USA, which may result in deviations from the price planned by the hedging strategy. The higher the correlation between the prices in the two markets, the more predictable the results of hedging strategies are.

The Serbian Capital Market Law provides for a possibility of establishing a commodity derivative market and the market for all other types of derivative securities $^{\S}$. Serbian legal framework in this area is not in line with the EU common regulation that is binding for all the EU Member States, primarily EMIR $^{* *}$ and MIFID 2. The need for further harmonization of the Law on Capital Market refers to the regulation of licensing and controlling of the clearing houses operations and clearing and reporting on swap contracts. After the Global economic crisis, financial market regulations around the world have been substantially harmonized ${ }^{\dagger \dagger}$, and therefore, by aligning with the EU, Serbia will be harmonized with the global financial market, thus creating the possibility for the development of the derivative securities market in Serbia.

\section{METHODOLOGY}

Research methodology includes the following:

- Literature review;

- Interview with leading experts in the field of risk management in the agricultural sector, as well as farmers and grain traders;

- The following statistical methods have been applied: (1) calculating the corn price variation degree in Serbia; (2) calculating the corn prices correlation and regression on the Commodity Exchange Novi Sad, CME and MATIF.

\footnotetext{
${ }^{\S}$ Law on Capital Market, Official Gazette of RS, no. 31 (2011).

** Regulation (EU) no. 648/2012 of the European Parliament and of the Council of 4th July 2012 on OTC derivatives, central counterparties and trade repositories (EMIR).

$\dagger$ On September 2009, at the Summit held in Pittsburgh, common models for functioning, regulation and control of financial markets were established.
} 
50 | THE POSSIBILITIES OF APPLYING HEDGING STRATEGIES ON INTERNATIONAL COMMODITY EXCHANGES

\section{RESULTS, ANALYSIS AND DISCUSSION}

Derivative commodity exchange trading is not established in Serbia so domestic producers are not able to apply hedging strategies on domestic commodity exchanges.

The analysis conducted in the paper is twofold. First, grain prices on Serbian spot market are correlated with prices on foreign commodity exchanges because a high price correlation is a prerequisite for a successful hedging strategy on a foreign commodity exchange. The analysis was also carried out from the perspective of tax treatment and other administrative conditions for the trading of Serbian farmers on foreign commodity exchanges. The reason for this analysis is the fact that inadequate tax policy can disrupt the actual trading and implementation of hedging strategies on foreign commodity exchanges.

Taking into account the high volatility of grain prices in Serbia and the fact that there is no domestic futures commodity exchange, the possibility of applying hedging strategies on foreign commodity exchanges has been analysed.

The price fluctuation of agricultural products is the main driver of development and trading in futures on the commodity-exchange markets. Price fluctuations are directly correlated with the need for farmers' hedging strategies, so the more pronounced price fluctuations are, the greater the need of the farmers to manage the risk of price changes on commodity exchanges (Kovačević and Milošević, 2017).

In order to demonstrate the growing need for the development of the derivative commodity market in Serbia, in addition to interviewing relevant experts in the field of commodity exchange trading and risk management in agriculture, the data on corn price fluctuation on three commodity exchanges - CME, MATIF and Commodity Exchange Novi Sad are analysed. The data include the daily prices of corn at commodity exchange closing time expressed in $\$ /$ ton. The time dimensions of data differ for each series - January 3, 2007 - May 25, 2018 for Commodity Exchange Novi Sad, January 13, 2010 - May 25, 2018 for data from CME, and May 12, 2011 - May 25, 2018 for MATIF data on corn prices.

Table 2 shows a significant fluctuation in corn price during the observed period, which leads to the conclusion that there is a pronounced need of domestic farmers for the implementation of hedging strategies and securing price in the future period. 


\section{Table 2}

Descriptive statistics - corn prices on Commodity exchange Novi Sad, for the period January 3, 2007 to May 25, 2018

\begin{tabular}{lc}
\hline \multicolumn{1}{c}{ Serbia } & Corn price \\
\hline Standard deviation & 55.31 \\
Variance & $3,059.14$ \\
Arithmetic mean & 192.77 \\
Variation coefficient & 0.29 \\
\hline
\end{tabular}

Note. Calculated by authors. Based on data from Commodity Exchange Novi Sad Retrieved from: https://www.proberza.co.rs/

No derivative agricultural market with high trading volume has been established in the region. Bearing in mind that the high volume of trading is a basic precondition for a successful implementation of hedging strategies, it is not expected that the individual Central and Eastern European countries will succeed in establishing an efficient derivative commodity exchange. The Budapest, Romania and Sofia commodity exchanges have low trading volumes ${ }^{\text {t. }}$.

To analyse the potentials for implementing the hedging strategy of Serbian farmers, the Chicago Mercantile Exchange and the MATIF have been selected as commodity exchanges with a high trading volume.

Since a large part of the Serbian export of grain is contracted and exported through the ports of the Black Sea, Black Sea Wheat FOB (Platts) and Black Sea Corn FOB (Platts) Futures and Options trading platform is also presented. Commodity exchange trading of Black Sea Wheat FOB (Platts) and Black Sea Corn FOB (Platts) Futures and Options organized by the Chicago Mercantile Exchange, represents a new derivative market for deliveries in Black Sea ports. Futures contracts are financially settled. This market shows a significant volume of trading that is increasing. Table 3 shows the number of open positions for corn futures on August 24, 2018.

\footnotetext{
$\$$ The initiative for the establishment of a common regional forward commodity exchange and the integration of turnover would enable efficient trading.
} 
52 | THE POSSIBILITIES OF APPLYING HEDGING STRATEGIES ON INTERNATIONAL COMMODITY EXCHANGES

Table 3

Black Sea Wheat FOB (Platts) and Black Sea Corn FOB (Platts) Futures and Options, the number of open corn futures positions on August 24, 2018

\begin{tabular}{lc}
\hline FUTURES & Number of open positions \\
\hline OCT 18 & 1,320 \\
NOV 18 & 1,140 \\
FEB 19 & 300 \\
TOTAL & 2,760 \\
\hline
\end{tabular}

Note. Authors' presentation based on the data from CME Group, retrieved from https://www.cmegroup.com/trading/agricultural/grain-and-oilseed/black-sea-cornfinancially-settled-platts_quotes_volume_voi.html?optid=8476\#tradeDate=20180824..

Correlation of prices of agricultural products is a basic precondition for applying hedging strategies on commodity exchanges.

By analysing variability indicators a significant volatility in the price of Serbian corn is noticed, which is indicative of the need for introducing commodityexchange forward trading. This would allow participants in the trading of agricultural products to apply hedging strategies in order to secure the price of agricultural products in the future. In the case of corn prices, there is a high degree of correlation in all three markets.

Table 4

Correlation matrix - prices of corn on Commodity Exchange Novi Sad (CMENS), CME and MATIF in the period from May 12, 2011 to May 25, 2018

\begin{tabular}{lrrr}
\hline & CMENS & CME & MATIF \\
\hline CMENS & 1 & & \\
CME & 0.903342 & 1 & \\
MATIF & 0.944925 & 0.945953 & 1 \\
\hline
\end{tabular}

Note. Authors' presentation based on the data from Commodity Exchange Novi Sad, CME Group and MATIF, retrieved from: https://www.proberza.co.rs/, www.cmegroup.com i https://www.euronext.com/en

The correlation coefficient between corn prices on the Commodity Exchange Novi Sad and MATIF is 0.945 . High positive correlation of corn prices between these two commodity exchanges is expected given that these markets are geographically close.

The positive correlation of corn prices between Serbia and the Chicago Mercantile Exchange is high (0.903), but somewhat lower than for MATIF. 
Irena Janković, Vlado Kovačević, Vladimir Zakić | 53 Based on the analysis carried out, it can be concluded that the MATIF commodity exchange in Paris is the most suitable for the implementation of the hedging strategies of Serbian farmers.

An analysis of the tax treatment of trading in foreign derivatives established that there are significant obstacles to trading. Tax regulations require issuing a proforma invoice in case of trading with companies abroad, which serves as the basis for payment to margin accounts. This cannot be applied in practice because the purpose of the payment in futures trading is the provision of deposit (margin) for the insurance of trading, and not the regular buying and selling of agricultural products. Inadequate tax practice in Serbia makes it difficult for domestic farmers to apply hedging strategies on foreign commodity exchanges, despite the need for managing the risk of price changes and high correlation between prices of domestic products and prices on foreign commodity exchanges.

\section{CONCLUSION}

A significant fluctuation in prices of agricultural products has led to a considerable need for farmers to manage this market risk. In order to manage the risk of unfavourable changes in prices, farmers in countries where there is a developed commodity-derivative market are able to apply the hedging strategy. Hedging strategies are based on the purchase and sale of highly standardized futures and options contracts,

Despite the fact that there is a legal possibility for the development of derivative commodity exchanges in Serbia, based on the Law on Capital Market, this market has not yet developed in Serbia. Consequently, farmers do not have the possibility to apply hedging strategies in order to protect the price of agricultural products against changes on domestic commodity exchanges in the future.

According to the results of the analysis in this paper, Serbian farmers have a pronounced need for hedging strategies, since there was a significant fluctuation in corn prices in the period 2007-2017.

The most favourable foreign commodity exchange for the implementation of the hedging strategies of Serbian farmers is MATIF in Paris, given that the correlation between corn prices in Serbia and those on the mentioned commodity exchange is the highest. Correlation of corn prices in Serbia and $\mathrm{CME}$ is also significant and it can be concluded that Serbian farmers can successfully apply their hedging strategies on this commodity exchange as well. 
54 | THE POSSIBILITIES OF APPLYING HEDGING STRATEGIES ON INTERNATIONAL COMMODITY EXCHANGES

Despite the pressing need for managing the unfavourable price change in the future period, as well as the fulfilled second condition for the hedging strategy abroad - a pronounced correlation of prices, Serbian farmers do not use foreign commodity exchanges due to inadequate tax policy. Tax regulations require the payment of margin money based on the pro-forma invoice, as in the case of regular trading on the basis of which the goods are delivered. In the case of forward trading on foreign commodity exchanges, such payment is not possible, since the goods are not delivered on the basis of future trading, but a cash settlement occurs between the buyer and the seller.

Recommendation is that necessary changes should be introduced in tax regulations and that Serbian farmers should be enabled to open margin accounts in order to secure trading, which would enable the free trading and implementation of hedging strategies on foreign commodity exchanges.

It would also be important to amend the Law on Capital Market and align it with the common EU regulations, thus creating a practical basis for the development of the commodity exchanges in Serbia.

\section{REFERENCES}

Arezki, R., Loungani, P., Ploeg, R., \& Venables, A. J. (2014). Understanding international commodity price fluctuations. Journal of International Money and Finance, 42, 1-8.

Assefa, T.T., Meuwissen, M., \& Lansink, A. G.J.M. O. (2017). Price risk perceptions and management strategies in selected European food supply chains: An exploratory approach. NJAS-Wageningen Journal of Life Sciences, 80, 15-26.

Gaudenzi, B., Zsidisin, G. A., Hartley, J. L., \& Kaufmann, L. (2018). An exploration of factors influencing the choice of commodity price risk mitigation strategies. Journal of Purchasing and Supply Management, 24(3), 218-237.

CME Group. Black Sea Wheat FOB (Platts) and Black Sea Corn FOB (Platts) Futures and Options. (2018). Retrieved from: https://www.cmegroup.com

Conlon T., Cotter J., \& Gençay, R. (2016). Commodity futures hedging, risk aversion and the hedging horizon. The European Journal of Finance, 22(15), 1534-1560.

Kolb, R. W., \& Overdahl, J. A. (2007). Futures, Options, and Swaps. Malden, USA: Blackwell Publishing. 
Irena Janković, Vlado Kovačević, Vladimir Zakić | 55

Kovačević, V., \& Milošević, I. (2017). Značaj i preduslovi razvoja berzankog trgovanja poljoprivrednim proizvoima u Srbiji. Škola biznisa, 2/2017, 172-178.

Kovačević, V. (2014). Razvoj robnih berzi u funkciji upravljanja rizikom poslovanja poljoprivrednih preduzeća u Srbiji (Doktorska teza). Poljoprivredni fakultet, Univerzitet u Beogradu.

Law on Capital Market, Official Gazette of RS, no. 31 (2011).

MATIF. Retrieved from: https://www.euronext.com/en

Mendelianae Brun. (2018). Acta Univ. Agric. Silvic., 66, 767-779 https://doi.org/10.11118/actaun201866030767, available at: https://acta.mendelu.cz/66/3/767/

Produktna Berza Novi Sad. Retrieved from: https://www.proberza.co.rs/

Regulation (EU) no. 648/2012 of the European Parliament and of the Council of 4th July 2012 on OTC derivatives, central counterparties and trade repositories (EMIR).

Taušer, J., \& Čajka, R. (2016). Hedging techniques in commodity risk management. Agricultural Economics, 60(4), 174-182.

Zakić V., \& Vasiljević Z. (2013). Uspostavljanje tržišta robnih derivata u funkciji unapređenja agrosektora u Srbiji. Ekonomski vidici, 18(1), 49-61.

Delivered: 03.11.2018. Accepted: 19.03.2019. 